\title{
NF1 Mutation Analysis Testing Method
}

National Cancer Institute

\section{Source}

National Cancer Institute. NF1 Mutation Analysis Testing Method. NCI Thesaurus. Code C158923.

A request to enter the specific molecular analysis method used to detect and identify mutations in the NF1 gene. 